\title{
A comunicação dissidente e os atos que falam
}

\section{The dissident communication and speech by the deeds}

Jacques A. Wainberg

Professor doutor do Programa de Pós-Graduação em Comunicação Social da Pontifícia Universidade Católica do Rio Grande do Sul (PUCRS)

<jacqalwa@pucrs.br>

\section{RESUMO}

Este estudo aborda um caso especial de comunicação, o utilizado por atores sociais dissidentes para transmitir suas mensagens através de encenações dramáticas. Casos são examinados e comparados. A comunicação dissidente é um tipo especial de discurso persuasivo. Ele almeja afetar o clima de opinião pública através de certo tipo de cenas, as que permitem enquadrar as emoções humanas que expressam a rebeldia e a crítica. Elas também permitem enviar a um públicoalvo específico uma mensagem política implícita. $\mathrm{O}$ significado é inferido dos gestos que se interligam no "jogo de cenas" da dramatização da mesma forma que um intérprete entende uma frase a partir do "jogo das palavras" no contexto da oração.

\begin{abstract}
This study elaborated on a special case of communication, used by social actors to convey their dissident messages through dramatic reenactments. Cases are examined and compared. The dissident communication is a special kind of persuasive speech. It aims to affect the climate of public opinion through the right kind of scenes, which allow framing the human emotions that express rebelliousness and criticism. They also allow sending to a specific target audience an implicit political message. The meaning is inferred from the gestures that are interconnected in the dramatization of scenes set in the same way that an interpreter understands a phrase from the play of words in the context of a sentence.
\end{abstract}

Keywords: Dissident communication.Speech by deeds. Discourse.

A "Comunicação Dissidente" se propõe a desafiar o senso comum, expressa publicamente o desconforto e a oposição que um ator cultiva a um ou a vários aspectos de certo sistema social, político, cultural, moral, religioso, organizacional e/ou civilizacional. O dissidente pode ser uma pessoa, um grupo, uma celebridade, um partido político, um movimento, um ativista, um intelectual, um religioso ou qualquer outro ator cuja ação pública ambicione alterar o clima de opinião vigente. A dissidência é uma interação que ocorre entre falantes/atores e ouvintes/auditório de maneiras diversas (Sai e Tomam 2002). Entre elas estão os discursos orais, o entretenimento, as petições, os slogans, as imagens, as caricaturas, a produção editorial, a imprensa, a cinematografia, a dramaturgia, as manifestações populares, os atos violentos (como o terrorismo) e os não violentos (como a desobediência civil) (Martin, 2008). 
Este estudo assume, portanto, a ideia de que a dissidência é inevitável. Sempre haverá alguém que, em algum grau, estará insatisfeito com certo aspecto da realidade existente. Cabe atentar, portanto para a dinâmica através da qual a tradição é abalada pela dissidência e como um novo conjunto de crenças, ideias ou práticas emerge na sociedade. A tensão que decorre do enfrentamento entre o novo e o velho é inevitável. Uma análise crítica do discurso dissidente permite revelar o que é assumido pelo falante, ou seja, o que está implicado em seu discurso (Streeter, 2013, p. 492). Ele necessariamente leva em conta "os recursos culturais que irão ressoar em suas sociedades e através de outras sociedades relevantes" (Wehner e Thies, 2014, p. 421).

A emergência da nova narrativa dissidente é um turning point que indica como os atores reagem e se posicionam frente às mudanças ocorridas no ambiente. Exemplos incluem a narrativa sobre os direitos humanos, a que emergiu e se solidificou no mundo após a libertação dos prisioneiros judeus do campo de concentração de Auschwitz (1945); a narrativa sobre os direitos civis dos negros, a que tomou fôlego nos Estados Unidos, em especial após o assassinato de Martin Luther King (1968); a narrativa sobre a verdade e o perdão, a que surgiu na África do Sul após a libertação de Nelson Mandela da prisão (1990); a narrativa sobre o ambientalismo, a que se disseminou pelo mundo principalmente após o acidente dos reatores atômicos de Three Mile Island (1979), nos Estados Unidos e de Chernobyl (1986), na Rússia, e a narrativa em favor da democracia e do liberalismo, a que se disseminou fortemente após o ataque da Al Qaeda, nos Estados Unidos, em 2001.

\section{Atos que falam}

Fazer algo com as palavras é o que Austin (1975) denominou de "ato de fala". Ocorre que é possível oferecer a ideia oposta, a de que a cena dissidente funciona como um discurso. Trata-se de um "Ato que Fala" ou [AqF]. Seu valor é tal que as palavras são desnecessárias. O significado é inferido dos gestos que se interligam no "jogo de cenas" da dramatização da mesma forma que um intérprete entende uma frase a partir do "jogo das palavras" no contexto da oração (Wittgentein, 1975). Este autor diz que o significado de uma palavra só pode ser entendido se compreendermos seu uso numa determinada situação. Ocorre o mesmo na escolha do ato cênico, deriva de sua adequação à intenção comunicativa do falante/intérprete. Ou seja, as cenas que constituem o ato se manifestam dentro do jogo simbólico da dramatização.

Portanto, o $[\mathrm{AqF}]$ funciona como uma proposição, já que ele expressa um pensamento e possui um conteúdo judicável. A cena não resulta de uma 
mistura aleatória de gestos, da mesma forma que um tema musical não é uma mistura qualquer de sons (Pinto, 1998). Pode-se dizer por isso que o [AqF] é um artifício linguístico. Cabe repetir: o contexto é interno quando o que se considera é o "jogo de cenas" que geram a representação dissidente, ou seja, o ato. Da mesma forma que a palavra, o $[\mathrm{AqF}]$ possui uma propriedade figurativa ao representar através de imagens um fato da realidade (Pinto, 1998). O seu contexto é externo quando ele é partilhado pelos interlocutores. $O$ ambiente dilemático que envolve a ambos é o que motiva a geração da ação dramática.

A relevância da situação para a comunicação foi exaltada originalmente pelo sociólogo americano William Isaac Thomas (1863-1947). O Teorema de Thomas diz que "o que realmente vale é a maneira como o ator define o significado de um símbolo, e não o que símbolo pode significar ao sociólogo que investiga as ações do ator" (MANN, 2008, p. 181-182). Para ele, uma situação representa a configuração dos fatores que condicionam uma reação comportamental (Thomas, 1928).

Sobre este tema é possível argumentar ainda que o [AqF] é um "truque de linguagem". A descrição deste truque se aproxima dos conceitos elaborados por Goffman em A Representação do Eu na Vida Cotidiana (1989). O autor diz na obra que o ator social pode escolher seu palco e sua peça, assim como o figurino que ele usará na representação. Kenneth Burke é outro autor que utiliza a metáfora teatral para explicar o fato de que o ser humano é um ator, pois desempenha papéis em interação simbólica com outras pessoas. A ação dramática, para Burke, é um comportamento deliberado, voluntário e livre. Cabe lembrar por isso sua pêntade dramática: O Ato (O que aconteceu? Qual é a ação?); a Cena (Onde o ato está ocorrendo? Qual é a situação ou contexto?); Agente (Quem e o que está envolvido na ação?); A atuação (Como o ator atua?) e o Propósito (Por que os atores atuam da forma que atuam?) (Burke, 1969).

Isso equivale a dizer que para cada situação cabe certo tipo de atuação. A comunicação dissidente viola esta máxima ao oferecer uma mensagem incompatível e desviante ao contexto. Por decorrência, um efeito chamariz logo se produz no polo da recepção. A cena dissidente chama a atenção do observador que se surpreende com a ousadia do ator pronunciar um discurso inesperado.

$\mathrm{O}$ [AqF] também se aproxima do "pseudoevento", conceito apresentado por Boorstin em sua obra The Image (1992). "Pseudoevento" é um acontecimento dramatúrgico construído de forma premeditada por ator interessado em consolidar na opinião pública certa imagem. É, portanto, um acontecimento manipulado que visa influenciar a opinião pública. Entre um e outro termo 
perdura, no entanto, uma diferença essencial: o [AqF] é um gesto crítico e tem valor político, por isso cabe dota-lo de potência. $\mathrm{O}$ [AqF] dissidente tem valor negativo, ou [AqF-]. Isso se deve à natureza dissonante desta encenação. Nos ambientes repressivos nos quais a liberdade de expressão é limitada, constrangida e vigiada o impacto do [AqF-] equivale ao de uma rebelião.

Conclui-se do dito que o gesto dissidente é um ato comunicacional pleno. $\mathrm{O}$ [AqF-] atua como um discurso. É um estimulo ostensivo que modifica o ambiente cognitivo e afetivo da audiência. Este tipo de Ato que Fala (AqF-) é altamente informativo por ser excepcional. E como nos discursos orais nos quais as pessoas escolhem o léxico e o estilo da manifestação, o [AqF-] também revela a intenção do ator. Resulta uma impressão causada à audiência através das cenas, do palco, do figurino e do cenário que o falante dissidente seleciona para sua elocução. Estes elementos formais se combinam na dramatização. A encenação é modelada com base na emoção que o dissidente deseja produzir no interlocutor. O relevante a destacar é o fato de que o silêncio do gesto dissidente implica n'algo, o de que o impronunciável será assim mesmo comunicado. Sua mudez é retórica e por isso mesmo ruidosa.

Por ser expressivo, todo mutismo é seletivo, mesmo o social. O não pronunciado é pista à decifração de seu significado profundo e verdadeiro. Ocorre que o significado do silêncio depende do contexto da interlocução (Gendron, 2011). Na perspectiva do [AqF-] não há mudez já que o silêncio é para linguagem, por isso que nos diálogos ordinários são feitas afirmações paradoxais tais como "a escuta do silêncio" (Madonik, 2001). Em suma, ao dissidente cabe à dura tarefa de pronunciar com seus gestos desviantes o indizível, mobilizar a opinião pública e romper a apatia (Rose, 2006; 2014).

O caso dos cartuns noruegueses que criticaram Maomé e que foram reproduzidos em 148 jornais de 67 países é exemplo pertinente ao papel exercido pela comunicação dissidente de alertar a comunidade dos perigos que rondam a unanimidade. Rose (2006) explica sua decisão de publicar as caricaturas como sendo uma resposta a vários incidentes de autocensura na Europa causados pelo aumento do medo e de sentimentos de intimidação ao se tratar de temas relacionados ao Islã. O termo "comportamento de manada" também se refere a esta tendência das pessoas seguirem os passos da maioria (Trotter, 2010). Por esta razão (e também por outras) é que as multidões têm sido objeto de desconfiança de vários autores (Freud, 2013; Canetti, 1995; Ortega e Gasset, 1971; Le Bon, 1895).

Exemploadicional de [AqF-] foi o ato realizado portrês jovens universitários gaúchos em 25 de fevereiro de 1975, conforme Figura 1. Eles subiram numa 
árvore visando impedir dessa forma seu corte. A ação ocorreu num contexto de forte repressão política, situação então existente no Brasil.

O gesto foi considerado pela autoridade da época como desviante, pois implicava em protesto e crítica social. Nesse período surgia o movimento ambientalista no país e a manifestação ecoou no clima de opinião pública que despertava para os problemas ecológicos. Prova disso foi à multidão que se formou à frente das árvores em apoio aos manifestantes. $\mathrm{O}$ caso foi classificado como ato subversivo e os três jovens acabaram presos pela polícia política da época, o DOPS (Departamento de Ordem Pública e Social).

- Figura 1 e 2- Estudantes protestam contra o corte de árvores em Porto Alegre, em 1975.
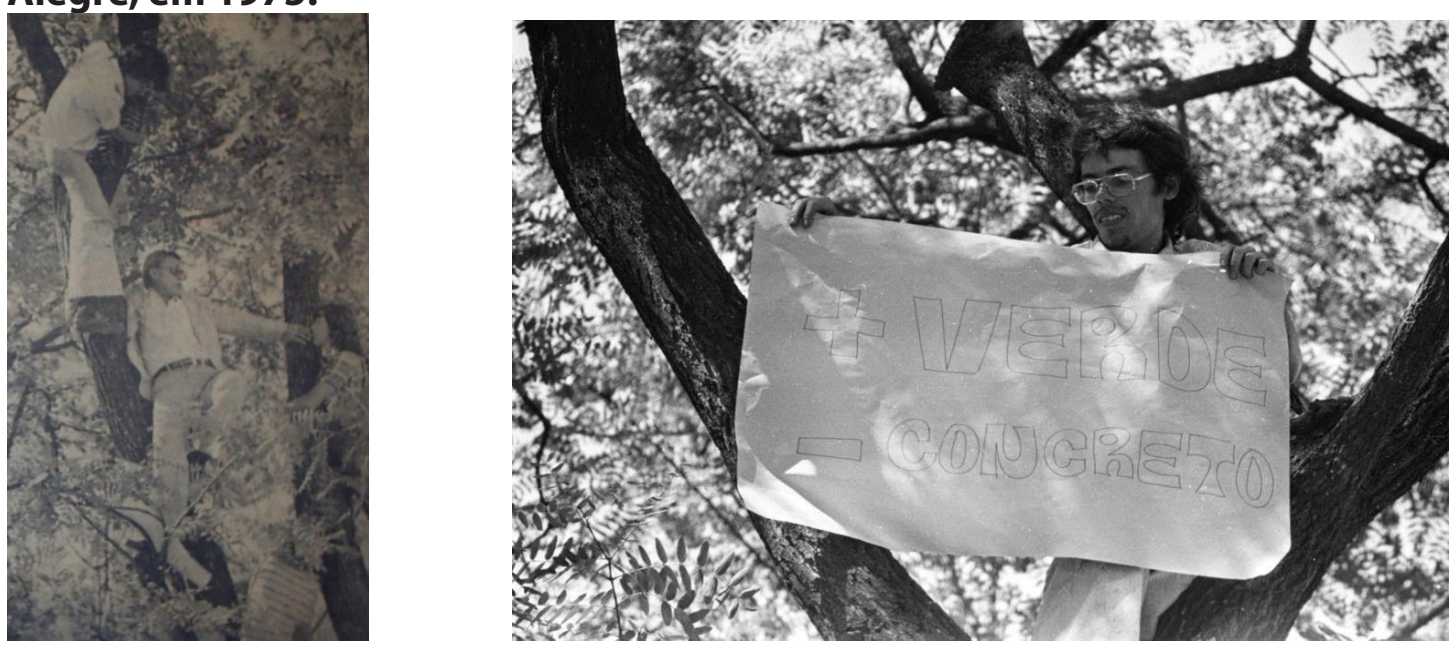

Fonte: Blog Outras Palavras Fonte: Clic RBS

A desobediência civil é outro tipo frequente de ato dissidente. Esta ideia foi formulada originalmente por Henry David Thoreau (1817-1862) num ensaio escrito em 1849 (Thoreau, 1997). Ele acabaria influenciando fortemente o anarquismo, vários autores (como Tolstoi), a militância de vários grupos (como o Movimento Solidariedade, na Polônia) e de ativistas (entre eles Mahatma Gandhi). A desobediência civil é a tática de luta aplicada hoje em dia pelo Black Bloc, um grupo anarquista que surgiu na Alemanha em 1980; pelo Reclaim the Streets, o grupo surgido em Londres na década de 1990 em protesto ao automóvel; pelo The International Attack Network, que luta pela regulação dos mercados financeiros internacionais; pelo grupo ecológico Earth First, surgido nos Estados Unidos em 1979; e pela Confederação Paysanne francesa. Casos de desobediência civil se multiplicam também no Brasil nas ações dos militantes da Via Campesina. 
Um dos principais teóricos contemporâneos da desobediência civil, o sociólogo americano Gene Sharp, listou 198 tipos de ações que se enquadram nesta categoria (Sharp, 1983)' ${ }^{1}$ Ele cita como exemplo clássico de dissidência civil a resistência ocorrida na Tchecoslováquia no período de 1968-69 contra a invasão do país pelas tropas da União Soviética. Outros exemplos são a resistência alemã na região do Ruhr contra as tropas de ocupação francesa e belga; a luta húngara contra o domínio austríaco entre 1850 e 1867 e a da Finlândia contra a russificação do país entre 1898 e 1905 (Sharp, 1980). Seus escritos parecem ter tido algum impacto na rebelião que depôs Hosni Mubarak no Egito, em 2011.

Conclui-se que o [AqF-] é um tipo de discurso mitigado, ocorre de forma indireta através de eventos carregados de valor dramático. $\mathrm{O}$ apelo à manifestação figurativa decorre do impacto que as imagens provocam no interlocutor, produzidas por terem uma propriedade publicitária, algo que as palavras não possuem.

\section{Estudo de Casos}

Portanto, o exame crítico de um [AqF-] demanda a análise (1) do contexto externo, ou seja, o dilema social/político/cultural enfrentado; (2) o contexto interno, o "jogo de cenas" da manifestação desafiadora; (3) a mensagem dissidente implicada na dramatização; (4) o ator principal, ou seja, o dissidente; (5) os atores coadjuvantes, em especial o opositor; (6) os atos cênicos desviantes; (7) o figurino; (8) o cenário (9) as intenções premeditadas pelo falante; (10) as emoções em jogo e (11) o efeito social e político causado pela produção do espetáculo.

O primeiro caso analisado se refere a um gesto histórico produzido em 1968 pelo movimento feminista. Bastou a insinuação da queima de sutiãs e de outros objetos femininos pelas militantes do Movimento de Libertação da Mulher que protestavam contra a realização do concurso Miss América em Atlantic City para que a cena fosse difundida por todo o mundo, atraísse a atenção do público, em especial o masculino, e fosse preservada até hoje como um símbolo da luta contra o machismo. Gestos similares foram replicados desde então em várias partes do mundo, como na Figura 3.

\footnotetext{
1 Disponível em: <http://www.aeinstein.org/wp-content/uploads/2014/12/198-Methods.pdf>. Acesso em: 3 mar. 2016.
} 
Figura 3 - O gesto de 1968. O protesto é replicado desde então.
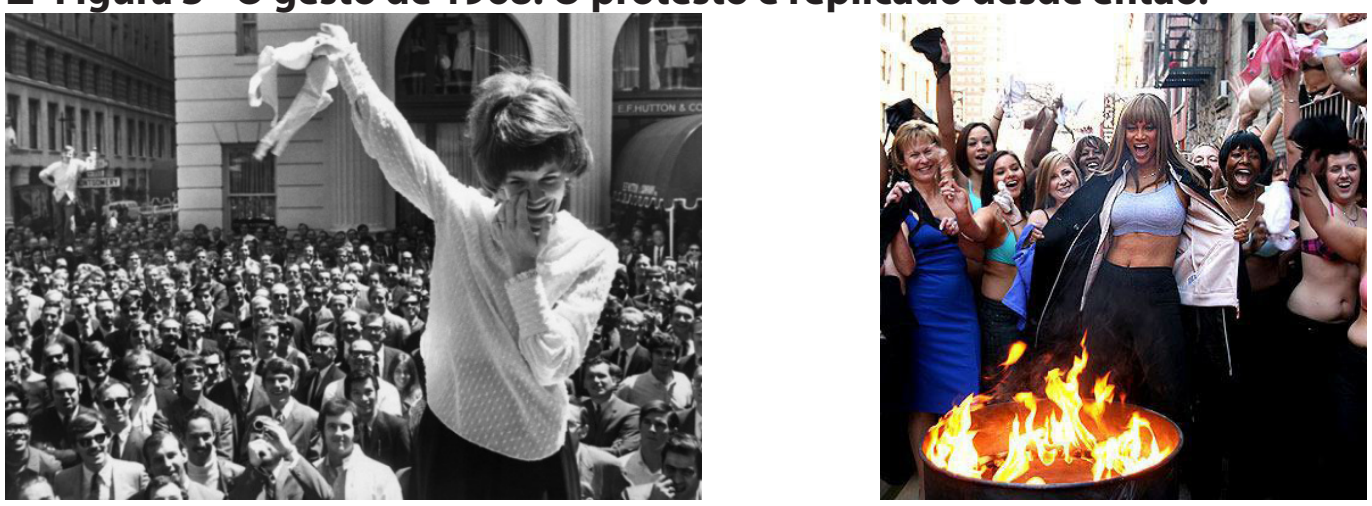

Fonte: KPBS Org.

A segunda ocorrência de "Fato que Fala" [AqF-] é a prisão de Louhain alHathoul na Arábia Saudita em 1 a de dezembro de 2014. Após cruzar a fronteira de seu país com os Emirados Árabes Unidos dirigindo um carro ela foi encarcerada por 73 dias. Desta maneira Louhain desafiou a norma que proíbe as mulheres conduzirem veículos no país. Em 1990, outras 50 sauditas foram presas pela mesma razão, entre elas, por exemplo, as militantes Maysa al-Amoudi e Manal al-Sharif².

\section{Tabela 1 - “Os Atos que Falam”: estudo comparado de casos vi}

\begin{tabular}{|l|l|l|}
\hline \multicolumn{1}{|c|}{ Tipo } & \multicolumn{1}{|c|}{ Manifestação Popular } & Desobediência civil \\
\hline Caso de [AqF-] & 1.A queima dos sutiãs & 2. Dirigir um automóvel \\
\hline Cena Disjuntiva & & $\begin{array}{l}\text { As mulheres são discriminadas } \\
\text { na Arábia Saudita. Este é o } \\
\text { único país do mundo onde } \\
\text { elas não podem dirigir } \\
\text { automóveis. }\end{array}$ \\
\hline $\begin{array}{l}\text { 1.0 contexto externo: } \\
\text { o dilema }\end{array}$ & $\begin{array}{l}\text { As mulheres são discriminadas nas } \\
\text { sociedades patriarcais do Ocidente. }\end{array}$ & \\
\hline
\end{tabular}

\section{Outras informações em:}

Mulheres dirigindo na Arábia Saudita. $<$ https://www.youtube.com/watch?v=sowNSH W2r0> $>$.

Entrevista com Manal Al Sherif. <https://www.youtube.com/watch?v=RO-9 B8e4zo $>$.

Manifestação de Manal Al Sherif. <https://www.youtube.com/watch?v=vNpmq6Ok-QQ>. 


\begin{tabular}{|c|c|c|}
\hline $\begin{array}{l}\text { 2. O contexto interno: } \\
\text { o jogo de cena }\end{array}$ & $\begin{array}{l}\text { O sutiã: o discurso é mediado por este } \\
\text { poderoso símbolo que remete ao corpo } \\
\text { feminino e ao seu poder de sedução. }\end{array}$ & $\begin{array}{l}\text { O automóvel: o discurso é } \\
\text { mediado por este símbolo que } \\
\text { remete à ideia de movimento, } \\
\text { autonomia e liberdade. Tais } \\
\text { valores são incompatíveis } \\
\text { com a posição ocupada pela } \\
\text { mulher nesta sociedade. }\end{array}$ \\
\hline $\begin{array}{l}\text { 3. A mensagem } \\
\text { dissidente }\end{array}$ & $\begin{array}{l}\text { A sociedade machista é intolerável. Tal } \\
\text { preconceito é inaceitável. }\end{array}$ & $\begin{array}{l}\text { A sociedade machista é } \\
\text { intolerável. Tal preconceito é } \\
\text { inaceitável. }\end{array}$ \\
\hline $\begin{array}{l}\text { 4. O ator principal: } 0 \\
\text { dissidente }\end{array}$ & A mulher & A mulher \\
\hline $\begin{array}{l}\text { 5. Os atores } \\
\text { coadjuvantes: o } \\
\text { interlocutor }\end{array}$ & O homem & O regime machista. \\
\hline 6. Cena disjuntiva & A queima do sutiã & $\begin{array}{l}\text { A mulher dirige o automóvel } \\
\text { sorrindo de maneira } \\
\text { desafiadora. }\end{array}$ \\
\hline 7. O figurino & $\begin{array}{l}\text { O sutiã e outros objetos de sedução da } \\
\text { mulher }\end{array}$ & A motorista \\
\hline 8. O cenário & A praça pública & A estrada \\
\hline $\begin{array}{l}\text { 9. A intenção } \\
\text { discursiva }\end{array}$ & Desafiar o preconceito machista. & $\begin{array}{l}\text { Desafiar o preconceito } \\
\text { machista. }\end{array}$ \\
\hline 10. A emoção em jogo & O respeito à mulher & $\mathrm{O}$ respeito à mulher. \\
\hline $\begin{array}{l}\text { 11. Os efeitos } \\
\text { persuasivos (retóricos) }\end{array}$ & $\begin{array}{l}\text { Apresentar uma nova narrativa, a da } \\
\text { liberdade feminina. }\end{array}$ & $\begin{array}{l}\text { Apresentar uma nova } \\
\text { narrativa, a da liberdade } \\
\text { feminina. }\end{array}$ \\
\hline
\end{tabular}

Fonte: $\mathrm{O}$ autor

Estes dois casos mostram a dimensão pragmática dos [Aqf-]s. Embora o dilema seja o mesmo (a discriminação contra as mulheres), a situação de cada manifestação impôs ao dissidente um tipo de expressão que levou em conta as características do contexto destes discursos. Na verdade, a forma de discurso adotada foi modelada pela circunstância. Este tipo de impacto foi denominado de priming em inglês e valência em português. Ele indica que as ações e as emoções humanas são condicionadas por eventos que produzem nas pessoas reações inconscientes. Experiências laboratoriais demonstram a veracidade

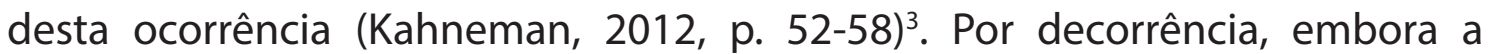

3 Cabe assinalar que há também evidências no sentido oposto, algo que foi denominado de "priming às avessas". Ou seja, as ideias são capazes de modelar os comportamentos. 
mensagem dissidente seja a mesma, os signos utilizados como marcadores retóricos (os que revelam a intenção do falante) nos dois casos diferiram ${ }^{4}$.

A Pragmática tem este mérito, ela permite a compreensão do uso da linguagem. Este é o tema que ocupa os filósofos da mente. $\mathrm{O}$ que os instiga é o fato de que a linguagem natural é ilógica, é vaga, é ambígua e se refere a objetos que não existem. Dito de outra maneira, o significado um enunciado não está totalmente encapsulado no que está codificado na sentença, mas na relação do que é dito com o contexto, algo que permite comunicar algo mais do que é simplesmente pronunciado. $O$ dito se refere ao representacional e o implicado na mensagem ao comunicacional (Sartori, 2014).

No caso 1 o cálculo inferencial a ser realizado pelo receptor funciona seguindo aproximadamente os seguintes passos: a) Só a mulher usa sutiã; b) Ou seja, o homem não usa sutiã; c) Quando o homem vê um sutiã ele pensa na mulher; d) Portanto o sutiã simboliza a mulher; e) As mulheres não queimam sutiãs; f) Se elas o fazem é porque elas querem dizer alguma coisa; g) Por que então elas queimam o sutiã?; h) Por que elas o fazem na praça pública?; i) Por que elas se mostram felizes e desafiadoras ao queimarem os sutiãs à vista dos homens?; j) Só pode ser uma representação, um espetáculo; i) E como tal ele tem uma mensagem; l) E a mensagem é: Vamos desafiar os homens. Abaixo o machismo!

No caso 2 os passos do cálculo inferencial são aproximadamente os seguintes: a) Na Arábia Saudita as mulheres não dirigem carros; b) A personagem, uma mulher saudita, aparece na estrada dirigindo um carro; c) É um ato proibido; d) Mas ela está sorrindo; e) Ela sabe que comete uma infração; f) Ela está feliz; g) Ou seja, ela desafia a autoridade; h) Por que ela desafia?; i) Ela quer dizer algo com isso; j) O quê?; I) Vamos desafiar os homens sauditas. Vamos desafiar as convenções sociais e religiosas. Abaixo o machismo!

\section{Conclusão e Considerações finais}

Os exemplos apresentados mostram que a dissidência é um discurso multicanal, criativo e mitigado. Como dito, nestes casos, como em muitos outros, o impronunciável é assim mesmo comunicado através de um ato cênico decifrável pelos interlocutores. Nesse sentido, a mudez é retórica. Ou seja, há nítida relação entre a dissidência, os atos escolhidos pelos atores e as cenas decorrentes que evocam a mensagem dissonante.

4 Não se deve confundir marcador retórico com marcador de discurso. O segundo tem a função de lubrificar a conversação sem propriamente participar dela. 
No polo da emissão aparecem o dissidente, seus gestos, o figurino e o cenário de sua performance. Uma história é contada através das cenas que se sucedem em sequências premeditadas pelo falante. O drama resulta do jogo destas cenas articuladas no contexto interno da representação, algo que remete à proposição do ato dissidente. Cabe salientar que tal declaração surge estimulada por certa situação, ou seja, o ambiente externo que lhe envolve.

A dissidência dramatúrgica é uma reação crítica aos dilemas vivenciais e existenciais que afetam de alguma maneira o rebelado. Se quiserem se entender falantes e ouvintes não podem perder o controle do jogo comunicacional. Eles aprenderam as regras deste tipo de relacionamento ao longo da vida. Ocorre que o dissidente viola propositadamente as máximas da polidez (Pinker, 2008), entre elas o tato, a generosidade, a concordância e a simpatia (Leech, 1983). Ou seja, o dissidente não faz a sua contribuição devida à conversação (Grice, 1975).

O apelo à nudez das militantes do Femen, à destruição terrorista no caso dos inúmeros ataques realizados por militantes salafistas e à desobediência civil, usual na atitude de movimentos sociais no Brasil, são atos cênicos similares em suas concepções e em seus propósitos. A propriedade figurativa da representação desviante tem sempre um efeito perturbador. Ele obriga as massas despertar da sonolência e a sair da zona de conforto e da alienação onde usualmente se refugiam.

A impolidez do dissidente abala igualmente o senso comum (Watts, 2003). Ser impolido significa agir contrariamente às vontades e aos desejos do outro (Pail, 2011). Além dos gestos agressivos e provocadores, a impolidez envolve outros recursos retóricos. Entre eles estão os xingamentos, os palavrões, a ironia, as gafes, os insultos, as ofensas e a violência. As cenas dissidentes são, por isso mesmo, disjuntiva e adversativa. No primeiro caso o [AqF-] propõe uma dicotomia radical. Na resolução do dilema ele sugere a opção: ou se aceita o status quo ou se acolhe a nova narrativa. Este é o reino do "OU" existente na linguagem verbal. A dissidência adversativa, por sua vez, é expressa na linguagem verbal pelo "MAS". O reino do "MAS" indica a oposição entre duas opções.

Cabe, portanto, acrescentar a potência negativa da proposição crítica dissidente a ideia, de grau de força emocional do que é enunciado. A emoção não deriva apenas do dito. A forma passa a ser relevante. A nudez Femen é pública. Sua ambição é política. A virulência argumentativa deste tipo de ato dramatúrgico se distingue fortemente de outro tipo de nudez, a praticada, por exemplo, nos espaços privados do naturalismo. Já a explosão de uma bomba 
num ônibus londrino ou num trem madrileno acarreta um grau máximo de virulência.

Exemplo do campo da moda foi o surgimento da minissaia em 1966, como nas figuras abaixo. Ela ocorreu num contexto de rebeldia política. A violação de um código estético que privilegiava até então a modéstia permitiu as mulheres desafiar o machismo com a exposição de seus corpos. Esta manifestação foi vista à época como agressiva, embora sedutora. Parecia ao espectador que algo estava sendo dito de maneira indireta com o desfile das pernas. A cena implicava num protesto aos padrões morais então vigentes. A comoção produzida pela minissaia redundou em vários casos de prisão das moças que acabaram cercadas nas ruas e vaiadas pelos populares. Em alguns lugares do mundo isso acontece ainda hoje.

Figuras 4 e 5 - Protesto em favor da minissaia em 1965 e o monoquíni na TV em 1964.

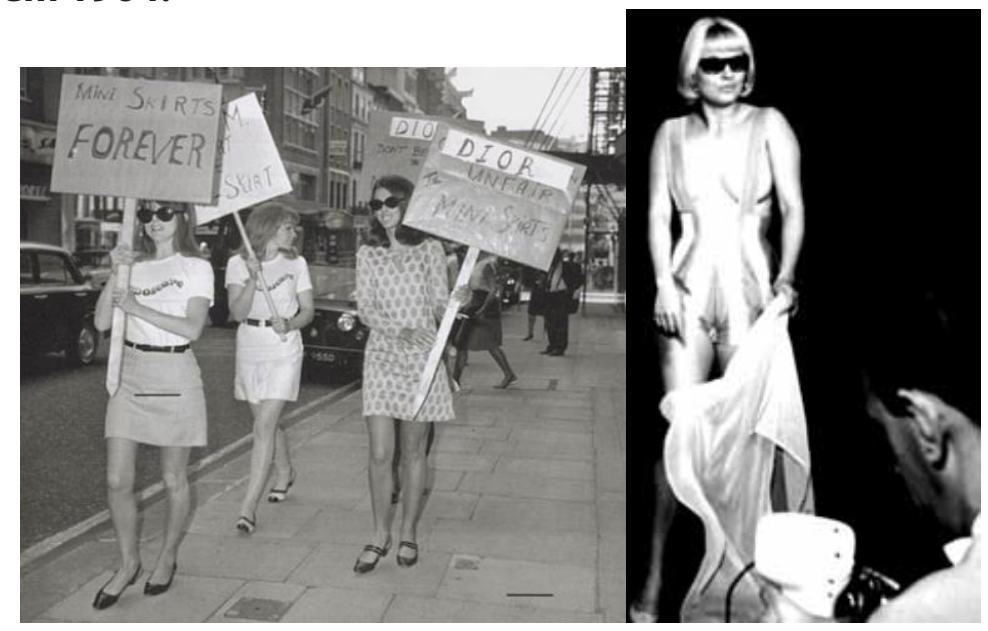

Fonte: Imagens Visions - Fernando Rabelo

A cena das mulheres de minissaia caminhando nas ruas se distinguiu da apresentação do monoquíni ocorrida no programa Show de Notícias, da TV Gaúcha de Porto Alegre, em 7 de julho de 1964. Ambos os casos testaram as convenções morais existentes à época. E ambos violaram a máxima da polidez. $O$ caso televisivo, no entanto, foi uma ocorrência (um discurso) que se inseria num contexto diversional. A comoção produzida pela aparição ao vivo de uma moça com boa parte dos seios desnudos e de óculos escuros (imagem que remetia à ideia de pecado) gerou a ira dos censores e do arcebispo de Porto Alegre. 0 secretário da Justiça da época, Paulo Brossard, reagiu tirando a emissora do ar por 24 horas. Em 1964, a nudez da modelo não pode ser enquadrada na esfera 
da comunicação política. A das militantes do Femen de hoje pode. A minissaia converteu-se com o passar do tempo em objeto trivial, algo similar ocorreu com a indumentária hippie e em seu lugar surgiu o hippie chique, como na figura abaixo.

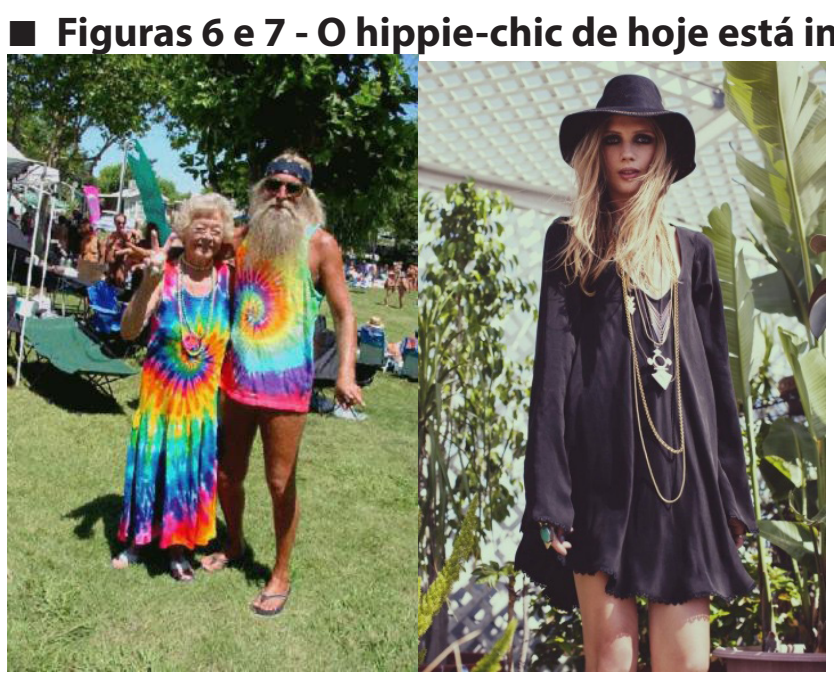

Fonte: Opa virou moda e Forever Boho

A moda tem o mérito de sugerir aos espectadores vislumbres do mundo do "MAS". O "MAS" dissidente é o que o falante quis dizer verdadeiramente e é ele, o "MAS", que autoriza as inferências do que está implicado no discurso. As sentenças livres de contexto revelam pouco das intenções do falante. Esta é a semântica dos lógicos. Não é o caso desta análise pragmática dos atos dissidentes que falam.

\section{CENA DISJUNTIVA/ADVERSATIVA -----> doravante denominada simplesmente de CENA DISJUNTIVA}

Há que se assinalar ainda que a comunicação dissidente culmina na"cena disjuntiva", uma manifestação retórica permeada pelo silêncio, pela emoção e pela teatralidade. Sob o ponto de vista cognitivo a decifração de uma imagem é sempre uma operação bem mais barata. Uma pessoa gasta menos energia para fazer o seu cálculo inferencial utilizando figuras do que a utilizada na inferência daquilo que permanece interditado, embora comunicado nas manifestações orais e textuais, como é o caso dos communiqués que os grupos revolucionários costumam divulgar a imprensa após seus atos terroristas. O ver para crer funciona neste campo que é o da forma. Cabe lembrar que nos exemplos mencionados 
até aqui as "cenas disjuntivas" referidas foram, entre outras, a queima do sutiã, a mulher saudita dirigindo o carro, as militantes do Femen nuas protestando nas ruas, os jovens de Porto Alegre dependurados nas árvores e a imolação.

Uma precisão maior do significado do termo pode ser obtida comparando as cenas disjuntivas com as figuras que se referem a eventos históricos marcantes. Por exemplo, a invasão da Normandia em 1944, a chegada do homem à lua em 1969 e o assassinato de John Kennedy em Dallas em 1963 marcaram a história e deixaram registrados numa ou em algumas imagens a dramaticidade da ocorrência, como na figura abaixo. São eventos que significam e que também 'falam', pois possuem um significado histórico profundo. O impacto dos mesmos projetou-se igualmente no tempo. Certamente, as imagens marcantes da história podem fazer parte de campanhas persuasivas. No entanto, o significado das mesmas é alegado pelo intérprete e não deriva da implicatura de um enunciado premeditado e concebido como um ato dissidente que fala pelo emissor. A imagem histórica não visa desafiar o senso comum estabelecido pelas convenções sociais.

- Figuras 8, 9 e 10 - Invasão da Normandia, chegada à lua e assassinato de Kennedy.

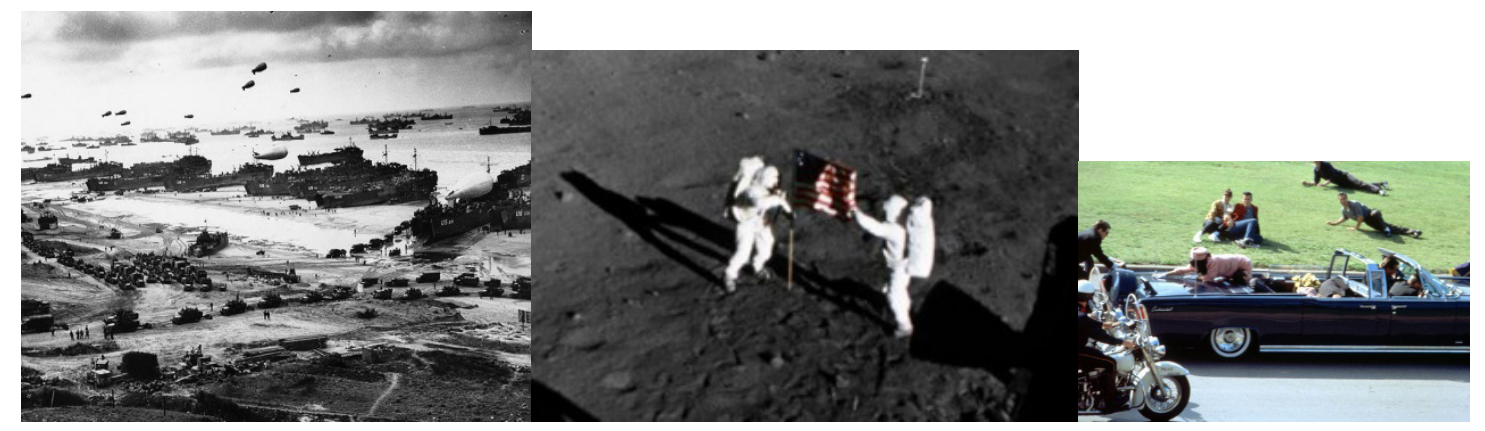

Fonte: Núcleo de Memória - PUC-RIO, PNLD Editora Moderna e Plano Brazil.

Há também casos inversos. Certas cenas disjuntivas se tornaram historicamente relevantes. É o caso das torres gêmeas explodindo em Nova York, pois permitirá as futuras gerações entender o momento de ruptura histórica causada por este ataque de militantes da Al Qaeda. Como o drama foi produzido de forma intencional e premeditada pode-se afirmar que o choque dos aviões nos edifícios foi concebido como ato retórico (propagandístico). 
Figuras 11, 12 e 13 - Sapato atinge Bush, Protesto Femen e avião derruba as torres

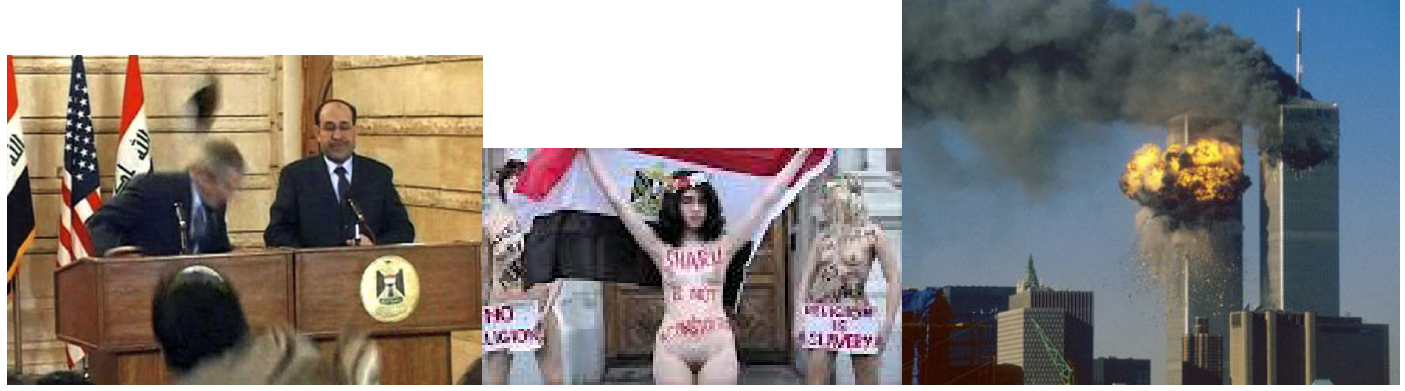

Fonte: G1

Com o tempo, e da mesma forma que a cena histórica marcante, a "cena disjuntiva"se converte em ícone. E como tal ela acaba sendo utilizada a posteriori no lugar da coisa representada. Isso acontece porque a "cena disjuntiva" permite despertar no observador uma emoção similar à original. Efeito parecido é o produzido pelo slogan e pelos gritos de guerra, e na comunicação religiosa pelos rituais.

No polo da recepção se acumulam os efeitos, variam em graus de emoção. Cabe acrescentar agora à fórmula apresentada a existência deste fator. Por isso $o$ ato dissidente passa a ser representado finalmente pela marca [AqF $\Delta$-]. Como exposto, a violação do princípio da cooperação é feita com este propósito de gerar uma implicatura. A fala gestual do dissidente é relevante aos propósitos da comunicação persuasiva porque ela salta aos olhos do observador. Com o tempo e com a insistência do rebelde, o que era tabu e vedado poderá, eventualmente, ser livremente comunicado. Os casos da minissaia, do feminismo e mais recentemente também do ambientalismo mostram que a dor do parto da comunicação dissidente, como a de todos os partos, é sempre dolorosa e leva algum tempo para germinar.

\section{REFERÊNCIAS}

AUSTIN, John. How to do things with words. Cambridge: Harvard University. 1975.

BOORSTIN, Daniel. The Image: A Guide to Pseudo-Events in America. Vintage. 1992.

BURKE, Kenneth. A Grammar of Motives. Berkeley: Universidade da California, 1969.

CANETTI, Elias. Massa e Poder. São Paulo: Cia das Letras, 1995. 
FREUD, S. A Psicologia das Massas e Análise do Eu. Porto Alegre: L\&PM Editores, 2013.

GASSET, José Ortega. A Rebelião das Massas. Rio de Janeiro: Livro Ibero-Americano, 1971.

GENDRON, Renée. 'The Meanings of Silence during Conflict.' Journal of Conflictology, v. 2, n. 1, 2011.

GOFFMAN, Erving. A Representação do Eu na Vida Cotidiana. Rio de Janeiro: Vozes, 1989.

GRICE, H. Paul. Logic and Conversation. In: Syntax and Semantics. New York, v. 3, p. 41-58, 1975. Disponível em: <http://www.sfu.ca/ jeffpell/Cogs300/ GriceLogicConvers75.pdf>. Acesso em: 3 mar. 2016.

JAKOVLJEVIC, Michel B.Shatterede Back Wall: Perfomative Utterance ofa Doll's Hous. Theatre Journal 54(3): 431-48, 2002.

KAHNEMAN, Daniel. Thinking, Fast and Slow. Londres: Penguin Books. 2012

LE BON, Gustave. Psicologia das multidões. São Paulo: WMF Martins Flores, 1895.

LEECH, Geoffrey. Principles of Pragmatics. London: Longman, 1983.

MADONIK, Barbara. I hear what you say, but what are you telling me? The strategic use of nonverbal communication in mediation. São Francisco, CA: Jossey-Bass, 2001.

MANN, Douglas. A Survey of Modern Social Theory. Canada: Oxford University Press, 2008.

MARTIN, Brian. Varieties of dissent. In Stephen P. Banks. Dissent and the Failure of leadership. Cheltenham: Edward Elgar, p. 22-36, 2008.

PAIL, Daisy Batista. A retórica da polidez e dos palavrões nas redes sociais: uma abordagem por interfaces. Porto Alegre: ediPUCRS, 2011.

PINKER, Steve. Do que é feito o pensamento: a língua como janela para a natureza humana. São Paulo: Cia das Letras, 2008.

PINTO, Paulo Roberto Margutti. Iniciação ao Silêncio. São Paulo: Edições Loyola. 1998. ROSE, Flemming. 'Why I Published Those Cartoons. Washington Post. 19/02/2006.

The Tyranny of Silence. Maryland: NATL Book Network. 2014

SANI, Fabio e TODMAN, John. Should we stay or should we GO? A social psychological 
model of schisms in groups. Personality and Social Psychology Bulletin. Califórinia, v. 28, n. 12, p. 1647-1655, 2002.

SARTORI, Roberta. 0 mundo dos implícitos no debate político-jurídico da eleição presidencial norte-americana de $\mathbf{2 0 0 0}$ através do discurso jornalístico: uma abordagem pragmático-lógico-cognitiva da inferência na interface com a comunicação. 2014. Tese (Doutorado em Letras) - Faculdade de Letras, PUCRS, Porto Alegre, 2014.

SHARP, Gene. Poder, Luta e Defesa. Porto Alegre: Paulinas, 1983.

Social Power and Political Freedom. Extending Horizon Books, 1980.

STREETER, Thomas. Policy, Politcs, and Discourse. Commnication, Culture \& Critique. New Jersey, v. 6, n. 4, p. 488-501, 2013.

THOMAS, William. The Definition of the Situation. In: Self, Symbols, and Society: Classic Readings in Social Psychology, Lanham, MD: Rowman \& Littlefield, p.103-115, 2002.

. The behavior pattern and the situation. Papers and proceedings of the Twenty-Second Annual Meeting of the American Sociological Society. V. $22,1928$.

THOREAU, Henry David. Desobediência Civil. Porto Alegre: L\&PM, 1999.

TROTTER, Wilfred. Instincts of the Herd in Peace and War. Nova York: FQ Legacy Books, 2010.

WATTS, Richard. Politeness. Cambridge: CUP, 2003.

WEHNER, Leslie; THIES, Cameron G. Role theory, narratives, and interpretation: the domestic contestation of roles. International Studies Review, v.16, n.3, p. 411436. 2014.

WITTEGENSTEIN, Ludwig. Investigações Filosóficas. São Paulo: Abril Cultural,1975.

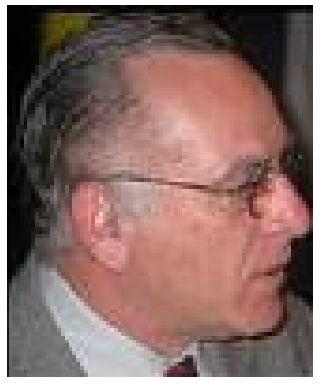

Recebido em: 07/04/2016

Aceito em: 14/04/2016

Endereço do autor:

Jacques Alkalai Wainberg <jacqalwa@pucrs.br>

Programa de Pós-Graduação em Comunicação Social da Pontifícia Universidade

Católica do Rio Grande do Sul (PUCRS)

Avenida Ipiranga, 6681 - Prédio 7 - Sala 319

90619-900 - Porto Alegre - RS - Brasil 